\title{
PERSONALITY CORRELATES OF MANAGERIAL TALENT: \\ CROSS CULTURAL COMPARISON
}

\author{
A.D. DE BOD* \\ AFDELING MANNEKRAG \\ SOUTH AFRICAN TRANSPORT SERVICES
}

L.W. SLAVINSKI
PUBLIC SERVICE COMISSION OF CANADA
OTTAWA

\section{OPSOMMING}

Ten spyte van die wêreldwye gebruik van die bestuursbeoordelingsentrum (AC) is daar tot dusver weinig kruiskulturele navorsing hieroor gedoen. 'n Verdere verwaarloosde area van AC-navorsing, is die bestudering van persoonlikheid. Hierdie studie ondersoek die verwantskap tussen bestuursdimensies en persoonlikheidsattribute van 'n groep Kanadese $(N=1199)$ en 'n groep Suid-Afrikaanse $(N=177)$ middelvlakbestuurders. Die eerste stap was om die meetinstrumente wat gebruik is te toets en die twee groepe te vergelyk. Die ingesamelde data vir beide groepe is aan 'n korrelatiewe en diskriminant-funksie ontleding onderwerp. Die ontledings is gebruik om (a) die persoonlikheidskorrelate van bestuurstalent te omlyn en (b) breë tendense bloot te lê ten opsigte van die relatiewe invloed van kultuur op die verwantskap tussen persoonlikheid en bestuurstalent.

Since Bray and Grant's (1966) pioneering work on the assessment centre method, there has been a rapid growth in the industrial application of the technique. From its initial use in just a handful of organizations in the mid-sixties in the United States an estimated 1000 plus organizations were using the method in 1975 (Finkle, 1976). In retrospect it seems clear that this phenomenal growth in the use of assessment centre technology, provided the impetus for similar applications outside the United States, in countries like Canada, Britain, Norway, Holland, Japan, Australia and South Africa.

The worldwide use of the assessment centre method has made it possible (if not necessary), for research to be done cross-culturally. However, up to now, the bulk of research (see reviews by Huck (1973), Finkle (1976), Klimoski and Strickland (1977), Byham (1980)) has been carried out within the context of a specific organization in a specific country.

\footnotetext{
* Requests for reprints should be send to the first author
} 
This study is intended as a modest addition to the relatively limited cross-cultural assessment literature. It also updates the other neglected area of assessment research, namely research on the relationship between personality traits and assessment centre dimensions. In a recent publication Bray (1982) summarized the latter issue as follows: "Operational assessment centres, those used for the selection of managers, observe thousands of personalities in action. They contribute very little, however, to the study of personality" (Bray, 1982, p. 183).

Any attempt to compare research results obtained in different countries with the aim to eventually make deductions as to the relative influence of culture, albeit only to detect broad tendencies, necessitates the use of similar (or at least comparable) measuring instruments. The first step in this study was therefore to compare the instruments used by the two organizations to assess managerial talent and personality.

\section{COMPARISON OF THE MEASURING INSTRUMENTS}

One of the prime features of an assessment centre is the use of managerial simulations as a method of evaluating managerial talent. Such exercises simulate the type of managerial work to which the participant would be exposed at a higher level, thus allowing his/her performance to be observed under quasi-realistic conditions.

The advantage of simulation exercises is that they allow evaluation of performance across a variety of situations and contexts, thus exposing the individual to as broad a range of managerial activity as possible. The individual can be observed in both structured and unstructured situations, assigned and non-assigned roles, competitive and co-operative settings, and on an individual or group basis.

In the assessment centres employed by the two organizations participating in this study, similar exercises are used to evaluate managerial talent, namely an in-basket, a structured leaderless group exercise, an analysis problem, a presentation exercise and an unstructured leaderless group discussion. In both assessment centres the assessors write assessment reports giving a description of the assessee's behaviour in the various exercises and presents his/her ratings on the dimensions assessed with specific behavioural examples to substantiate the ratings given. Although the dimensions which are evaluated in the two assessment centres differ 
by name, their underlying behaviour domain does not differ, as is apparent from a comparison of the operational definitions of the dimensions set out in Table 1.

\section{TABLE 1}

COMPARISON OF THE OPERATIONAL DEFINITIONS OF THE DIMENSIONS EVALUATED BY THE TWO ASSESSI.ENT CENTRES

\begin{tabular}{|c|c|c|c|}
\hline & $\begin{array}{l}\text { CANADLAN ASSESSMENT } \\
\text { CENTRE }\end{array}$ & & $\begin{array}{l}\text { SOUTH AFRICAN ASSESSMENT } \\
\text { CENTRE }\end{array}$ \\
\hline \multirow[t]{2}{*}{ DLEASION } & DEFINITION & DIMENSIOH & DEF INITION \\
\hline & Not Eesured. & $\begin{array}{l}\text { SELF- } \\
\text { DEVELOPKENT }\end{array}$ & $\begin{array}{l}\text { Evidence of preparedneas to develop his oun } \\
\text { abilitles/akilla in order to prepare/equip } \\
\text { hlagelf better for a asnagerial position. }\end{array}$ \\
\hline CREATIVITY & $\begin{array}{l}\text { To damonotrate tluancy and flaxibility } \\
\text { of thought and to diaplay } \Delta \text { traoh approach } \\
\text { to probleas by coning up with both the uaeful } \\
\text { and the unuaus. }\end{array}$ & IHITIATIVE & 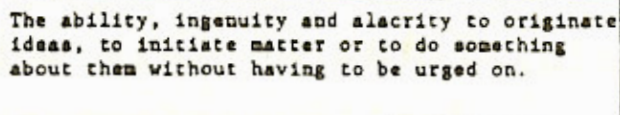 \\
\hline INTEILIGEICE & $\begin{array}{l}\text { To uge past knowladge or analytic and } \\
\text { gynthetic abilitiea fo order to achleve the } \\
\text { most appropriate outcoses oz solutiong for } \\
\text { probleas. }\end{array}$ & & Hot messured. \\
\hline MOTIVATIOK & $\begin{array}{l}\text { To show active interest and 1nvolvemeat in } \\
\text { takis, being highly comitted witb a ot rong } \\
\text { disire to vork, achleve and excel. }\end{array}$ & TENACITY & $\begin{array}{l}\text { The capacity to paraevere with a cask deapite } \\
\text { any opposicion/obatacies which any be } \\
\text { encountered. }\end{array}$ \\
\hline INDEPEADEACE & $\begin{array}{l}\text { To acate, purous and defend peraonal con- } \\
\text { victions uith toughness and courage leading } \\
\text { to effective courses of action. }\end{array}$ & DECISIVEAESS & $\begin{array}{l}\text { The ability to anke decisions without } \\
\text { healtation and to accept responsibility } \\
\text { therefor. }\end{array}$ \\
\hline LEADERSHIP & $\begin{array}{l}\text { To influence, convince, direct and peraunde } \\
\text { othera 1n order to get the job done: take the } \\
\text { lead in a group and to be abla to anintain } 1 \text {. }\end{array}$ & $\begin{array}{l}\text { TASR } \\
\text { STRUCTURING }\end{array}$ & $\begin{array}{l}\text { The ability to guide individuals and groupa } \\
\text { effectively towards the atcainast of a goal. }\end{array}$ \\
\hline $\begin{array}{l}\text { INTERPERSONAL } \\
\text { RELATIONS }\end{array}$ & $\begin{array}{l}\text { To get along with othere by beeting people } \\
\text { readily, interacting varmly, and responding } \\
\text { appropriately to the "personal" attuation at } \\
\text { hand; to show flexiblilty, tactfulaess and } \\
\text { falroes. }\end{array}$ & MAPATHY & $\begin{array}{l}\text { Eeal concern for the needo and foelings of } \\
\text { othern; personal varath and encouragedent. }\end{array}$ \\
\hline \multirow[t]{2}{*}{$\begin{array}{l}\text { PLANAIING AND } \\
\text { ORGANIZING }\end{array}$} & $\begin{array}{l}\text { To plan tasks and activities anking effective } \\
\text { and systemaric use of time and available } \\
\text { recources. }\end{array}$ & $\begin{array}{l}\text { PLANWING AND } \\
\text { ORGNIIIING }\end{array}$ & $\begin{array}{l}\text { The ability to physically define opecific } \\
\text { goals clearly, to mobilise in aysteantic and } \\
\text { orderly eanner the means for that purpose and } \\
\text { to co-ordinate and control tha necesany } \\
\text { activitiea. }\end{array}$ \\
\hline & Not nassured. & FLEXIBILITT & 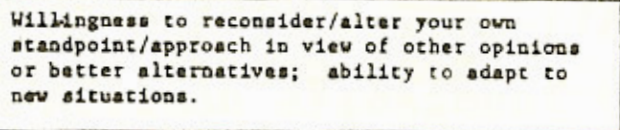 \\
\hline DEZEGATION & $\begin{array}{l}\text { To appropriately dealgate responsibility } \\
\text { and refer probleas or activities for effective } \\
\text { action. }\end{array}$ & $\begin{array}{l}\text { UTILISATION } \\
\text { AND } \\
\text { DEVELOPHENT }\end{array}$ & $\begin{array}{l}\text { The ability to utilise the capabilitiea of } \\
\text { othera and to develop them syateasically to } \\
\text { graser efficiency. }\end{array}$ \\
\hline $\begin{array}{l}\text { ARALYSIS AND } \\
\text { SYMTHESIS }\end{array}$ & $\begin{array}{l}\text { To analyze probleas 1nto their component parts } \\
\text { and to put together diverse ideas from a } \\
\text { variety of aources to arrive at effective } \\
\text { solutions and plans of actions. }\end{array}$ & $\begin{array}{l}\text { AHALYTICAL } \\
\text { ABILITY }\end{array}$ & $\begin{array}{l}\text { The ability to grasp the implicacions of a } \\
\text { situation quickly, to identify the relevant } \\
\text { data and to deteraine the root cauge/source } \\
\text { of a problea. }\end{array}$ \\
\hline $\begin{array}{l}\text { ORAL } \\
\text { CORAHICATIOXI }\end{array}$ & $\begin{array}{l}\text { To trangalt 1deas and inforeation with } \\
\text { claricy and pose in an lntereating and } \\
\text { articulate aanner; to use good vording and } \\
\text { gremar. }\end{array}$ & $\begin{array}{l}\text { REASONING } \\
\text { POWER } \\
\text { ORUL } \\
\text { PRESENTATICN }\end{array}$ & 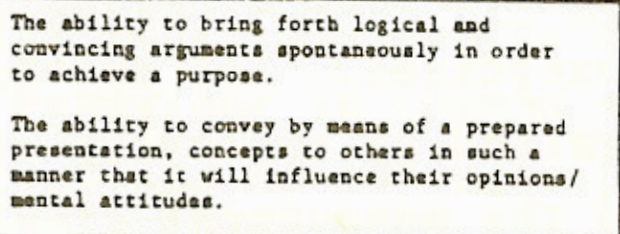 \\
\hline $\begin{array}{l}\text { QOALITI OP } \\
\text { JUDCEIETT }\end{array}$ & $\begin{array}{l}\text { To be objective in making eound judgements } \\
\text { concernigg the analyolo of probleas and che } \\
\text { evaluation of paople; does not allow ona's } \\
\text { own blases to distort the facts. }\end{array}$ & JUDGEMENT & $\begin{array}{l}\text { The ability to arrive at logical conclusions } \\
\text { and to display sound senae in the oolueion of } \\
\text { probleas. }\end{array}$ \\
\hline
\end{tabular}


By looking at the assessee from many different perspectives over the length of the assessment program (different dimensions, different assessors, different exercises), it is possible to arrive at a point where sufficient and reliable predictions of talents can be made. At both assessment centres the assessors consequently conclude (summarize) their decision in a so-called Overall Assessment Rating (OAR) which divides assessees into the following three groups:

GO

"Yes, at this point in time, based on this individual's performance in a simulated senior executive position and in the judgement of the assessors at the assessment centre, he/she has the potential to reach the senior executive level".

NO GO "No, at this point in time, based on this individual's performance in a simulated senior executive position, and in the judgement of the assessors at the assessment centre, he/she does not have the potential to reach the senior executive level".

UNCERTAIN "It was not possible on the basis of the individual's performance in a simulated senior executive position and in the judgement of the assessors at the assessment centre to predict with any degree of certainty whether he/she has or does not have the potential to reach the senior executive level".

The OAR is the sum total of the different perspectives which are gathered from a person's participation in the various simulated exercises. Yet another perspective of the individual is often gained by employing other assessment techniques in addition to the management simulations.

Within any assessment centre program it is common for simulation exercises to be combined with one or more other assessment tool including paper-and-pencil tests, selection interviews, records of past experience, career progression and employee appraisals. Each different assessment tool adds further relevant information that will assist in making appropriate decisions about the individual.

In the two assessment centres under discussion, the assessees also complete, in addition to the simulation exercises and the in-basket test, certain tests of mental ability as well as a personality questionnaire. These tests are intended to measure some of the factors within the general domain of cognitive abilities and interpersonal relations, however not all this information is utilized by the assessors in arriving at their overall assessment rating for an assessee. 
Since this study investigates the relationship between personality traits and assessment centre behavioural dimensions, only the personality questionnaires which are used in the two assessment centres will be described. The Personality Research Form (PRF) (Jackson, 1967) is used in the Canadian Assessment Centre, while the 16 Personality Factor Questionnaire (16 PF) (Cattell, 1970) is used in the South African assessment centre.

The PRF consists of 400 true-false items which are combined into 22 scales to measure the strength of various motivational factors. Generally, each scale represents a relatively independent personality trait, such as achievement, dominance, etc. which is influential in determining behaviour in common situations (See Annexure 1). The 16 PF consists of 187 multiple choice items. These items describe certain attitudes, reactions, etc. in the form of statements and the testee has to indicate whether these are true, false or uncertain as applied to himself. Responses to the items are combined to measure sixteen primary personality factors (See Annexure 2).

From the above it is clear that the two personality instruments are not in every respect similar, but when one carefully scrutinizes the high score descriptions of the personality traits measured (see Annexure 1 and 2), it seems safe to conclude that the questionnaires measure very much the same thing. This deduction however, is intuitive and thus unacceptable for any scientific purposes, unless it can be confirmed by either a conceptual/logical process or by empirical findings, but preferably by both.

In order to conceptually and logically verify the similarity between the PRF and the $16 \mathrm{PF}$, four clinical psychologists fully conversant with both questionnaires, were asked to independently compare the two sets of scales and to indicate which of them measure the same basic personality trait.

The postulate was that if there was unanimous agreement on any of the scales, they could be used when comparing the Canadian and South African research results. The outcome of this exercise is tabulated in Table 2.

Empirical evidence on the relationship between the PRF and 16 PF will serve to strengthen any ties that are made conceptually between scales. Unfortunately empirical evidence to substantiate the conceptual connection between the various PRF and 16 PF scales, as set out above, could not be found, thus limiting the validity with which similarities between the Canadian and South African research could be generalized. 
COMPARISON OF THE PRF AND 16 PF SCALES

\begin{tabular}{|c|c|c|}
\hline PRF SCALES & 16 PF SCALES & * \\
\hline Abasement & 0 & (E) \\
\hline Achievement & No agreement & $(Q 2, C, E, F)$ \\
\hline Affiliation & A & $(\mathrm{Q} 2)$ \\
\hline Aggression & L & $(E, Q 4)$ \\
\hline Autonomy & M & $(A, Q 1,02)$ \\
\hline Change & $F$ & \\
\hline Cognitive Structure & Q2 & $(G, Q 3)$ \\
\hline Defendece & $\mathrm{L}$ & \\
\hline Dominance & No agreement & (E) \\
\hline Endurance & C & (I) \\
\hline Exhibition & $\mathrm{H}$ & (M) \\
\hline Harmavoidance & No agreement & \\
\hline Impulsivity & $E$ & $(F)$ \\
\hline Nurturance & L & (A) \\
\hline Order & No agreement & $(0,3)$ \\
\hline Play & F & $(0, L)$ \\
\hline Sentience & I & $(\mathrm{H}, \mathrm{M})$ \\
\hline Social recognition & G & $(Q 3, Q 2)$ \\
\hline Succorance & No agreement & (I) \\
\hline Understanding & Q1 & \\
\hline Desirability & Q3 & $(C, G)$ \\
\hline Infrequency & B & \\
\hline
\end{tabular}

* Scales on which there were partial agreement are indicated in brackets

On the whole however, there appears to be enough similarity between the measuring instruments to allow at least a comparison of the research results with the aim to establish broad tendencies. The research was carried out against this background.

\section{METHOD}

The two subject groups for this study were formed by all the middle managers who participated in the respective assessment centres since their inception. The Canadian assessment centre was initiated in 1973 while the South African centre was initiated in 1978. Since then 1,199 and 177 middle managers have participated in the two assessment centres respectively. These individuals constitute the two subject groups of this study. For each 
subject in the Canadian group 13 behavioural measures (12 assessment centre dimensions plus 1 overall assessment rating) and 22 personality (PRF scales) measurements were available. The South African subjects had a similar amount of behavioural measurements, but only 16 personality measurements. The assessment centre ratings for both groups are ratings on a 7 point scale, while the OAR is a 3 point scale of 1 for a "NO" rating, 2 for an "UNCERTAIN" rating and 3 for a "YES" rating. The personality measurements are the raw scores obtained on the respective questionnaires. The data on the two groups was treated separately. It was only after this analysis that the results were compared, but then only on the measurements which were comparable (10 behavioural measurements (see Table 1), 16 personality measurements (see Table 2), 26 measurements in total).

Table 3 shows the correlations between the 22 PRF scales and the 13 behavioural ratings for the Canadian group.

TABLE 3

CORRELATION OF PRF SCALES WI'TH ASSESSMENT CENTRE DIMENSIONS AND OVERALL ASSESSMENT RATING $(\mathrm{N}=1199)$

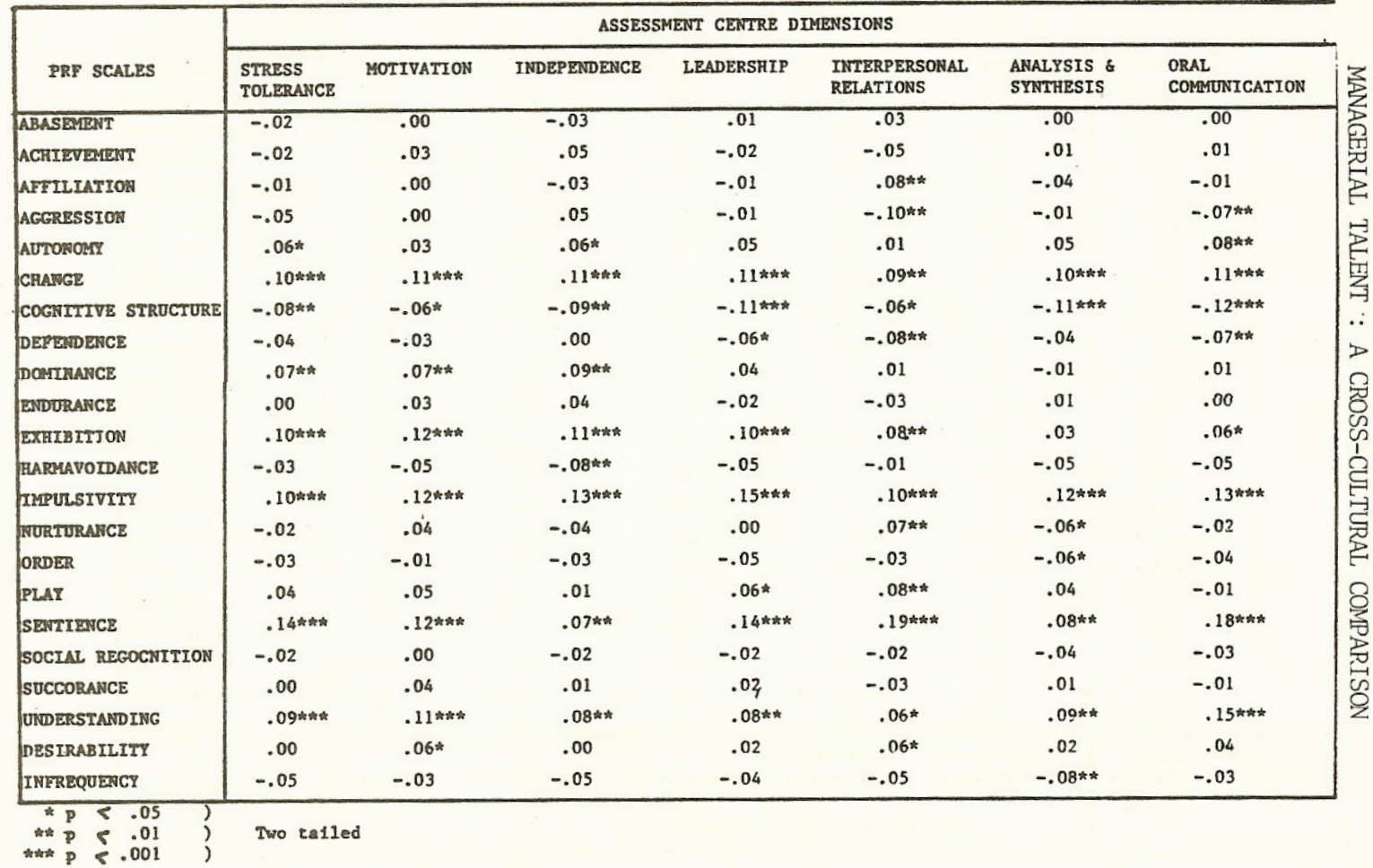


TABLE 3 (CONTINUĖD)

\begin{tabular}{|c|c|c|c|c|c|c|}
\hline \multirow[b]{2}{*}{ PRF SCALES } & \multicolumn{5}{|c|}{ ASSESSMENT CENTRE DIMENSIONS } & \multirow[b]{2}{*}{$\begin{array}{l}\text { OVERALL ASSESSMENT } \\
\text { RATING (OAR) }\end{array}$} \\
\hline & JUDGFMENT & INTELLIGENCE & CREATIVITT & $\begin{array}{l}\text { APPRORIATF, } \\
\text { DELEGATION }\end{array}$ & $\begin{array}{l}\text { PLANNING \& } \\
\text { ORGANIZTNG }\end{array}$ & \\
\hline ABASEMENT & .00 & -.02 & .01 & .01 & -.02 & -.02 \\
\hline ACHIEVFMENT & -.02 & -.05 & .04 & $.10 * * *$ & .01 & .01 \\
\hline AFFILIATION & -.02 & -.01 & $.06 *$ & -.04 & .02 & .00 \\
\hline AGGRESSION & -.01 & -.03 & -.01 & .01 & .02 & -.01 \\
\hline AUTONOMY & -.03 & $.06 *$ & .05 & .01 & .00 & .04 \\
\hline CHANGE & .01 & $.06 *$ & $.14^{\text {ktat }}$ & $.09 \div * \pi$ & $.08 * \approx$ & $.08 * \pi$ \\
\hline COGNITIVE STRUCTURE & 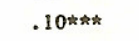 & $-.13 * \hbar *$ & $-.18=\pi k x$ & $-.11 * * * k$ & $-.07 * \pi$ & $-.10^{20 x t}$ \\
\hline DEFENDENCE & $-.08^{* 2}$ & -.05 & -.02 & .02 & -.05 & -.03 \\
\hline DOMTNANCE & -.04 & -.03 & $.09 * \pi *$ & -.01 & $.07 * *$ & .00 \\
\hline ENDURANCE & -.03 & -.04 & .02 & -.04 & .04 & .01 \\
\hline EXHIBITION & .00 & -.04 & $.03^{\mathrm{mt}}$ & -.03 & $.07 * k$ & .04 \\
\hline HARMAVOIDANCE & -.01 & $-.06 *$ & -.11 챚k & -.03 & -.03 & -.03 \\
\hline IMPULSIVITY & $.11 k \pi *$ & $.15 * \pi k$ & $.13 \% * k$ & $.08 * *$ & $.06 *$ & $.13^{\text {कारत }}$ \\
\hline INURTURANCE & -.03 & $-.11 \leqslant * *$ & -.02 & $-.06 *$ & .03 & -.03 \\
\hline ORDER & $-.06^{\text {t }}$ & $-.19 k * k$ & $-.15 \% * \pi$ & $-.10 \div \frac{\pi}{\hbar}$ & .00 & -.05 \\
\hline PLAY & .03 & -.01 & .03 & .00 & .02 & .04 \\
\hline SENTIENCE & $.10 \div \approx k$ & $.17 * * \pi$ & 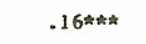 & .05 & $.06 *$ & $.15 * 2 *$ \\
\hline SOCIAL REGOCNITION & -.03 & -.05 & -.01 & .02 & .00 & .00 \\
\hline SUCCORANCE & .02 & .02 & .00 & .02 & .02 & .02 \\
\hline UNDERSTANDING & $.07 k$ k & .20 tht & $.18^{\mathrm{m} m \mathrm{t}}$ & $.08^{\text {*k }}$ & $.06 \%$ & $.10^{\text {thtkt }}$ \\
\hline DESIRABILITY & .02 & $.06 *$ & $.09 k n$ & .02 & .00 & .03 \\
\hline INFREQUENCY & $-.07 * \hbar$ & $-.06 *$ & -.04 & $-.06 *$ & .02 & -.05 \\
\hline 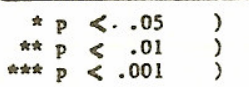 & Two tailed & & & & & \\
\hline
\end{tabular}

Several points emerge from Table 3:

- All the behavioural dimensions correlated significantly with some, though not necessarily the same sub-scales of the PRF. Judgement for instance correlated significantly with 6 scales while interpersonal relations showed 10 significant correlations. Creativity, intelligence, independence and oral communication also showed significant correlations with various personality traits.

- $\quad$ Only 4 of the 22 PFR scales did not correlate at all with the behavioural dimensions (abasement, endurance, social recognition, succorance).

- Cognitive structure, impulsivity, sentience and understanding showed the most significant correlations with the behavioural dimensions. These personality traits also correlated significantly with the overall assessment rating.

A correlational analysis was also performed on the South African data. The results are displayed in Table 4.

From the correlation matrix the following can be deducted: 
- Four of the behavioural dimensions (initiative, judgement, flexibility, analytical ability) showed no correlation with the 16 personality traits. The remaining dimensions significantly correlated with at least 1 of the $16 \mathrm{PF}$ scales (empathy), and at the most with 7 of the 16 scales (utilization and development).

- Only 3 of the 16 PF scales did not correlate at all with the behavioural dimensions (B, C, Q3).

- $\quad$ Factors E and Q2 showed the most significant correlations with the behavioural dimensions. These factors as well as factors F, H and Q1 correlated significantly with the overall assessment rating.

On the whole it seems safe to say that managerial talent definitely has certain personality correlates. To further establish the validity of the relationship between managerial talent and personality, a discriminant function analysis was performed on the personality scales (the PRF scales in the case of the Canadian group and the 16 PF scales in the case of the South African group) using the OAR as the classifying variable. The breakdown of the two subject groups with respect to this variable was as follows (Table 5):

TABLE 5

BREAKDOWN OF THE TWO SUUBJECT GROUPS USING THE OAR AS CLASSIFYING VARIABLE

\begin{tabular}{lcc}
\hline & $\begin{array}{c}\text { CANADIAN } \\
(\mathrm{N}=1 \text { 199) }\end{array}$ & $\begin{array}{c}\text { SOUTH AFRICAN } \\
(\mathrm{N}=177)\end{array}$ \\
\hline "NO" & 446 & 43 \\
"UNCERTAIN" & 159 & 94 \\
"YES" & 594 & $\underline{40}$ \\
& $\underline{1199}$ & $\underline{177}$ \\
\hline
\end{tabular}


TABLE 4

CORRELATION OF 16 PF SCALES WITH ASSESSMENT CENTRE DIMENSIONS AND OVERALL ASSESSMENT RATING $(\mathrm{N}=177)$

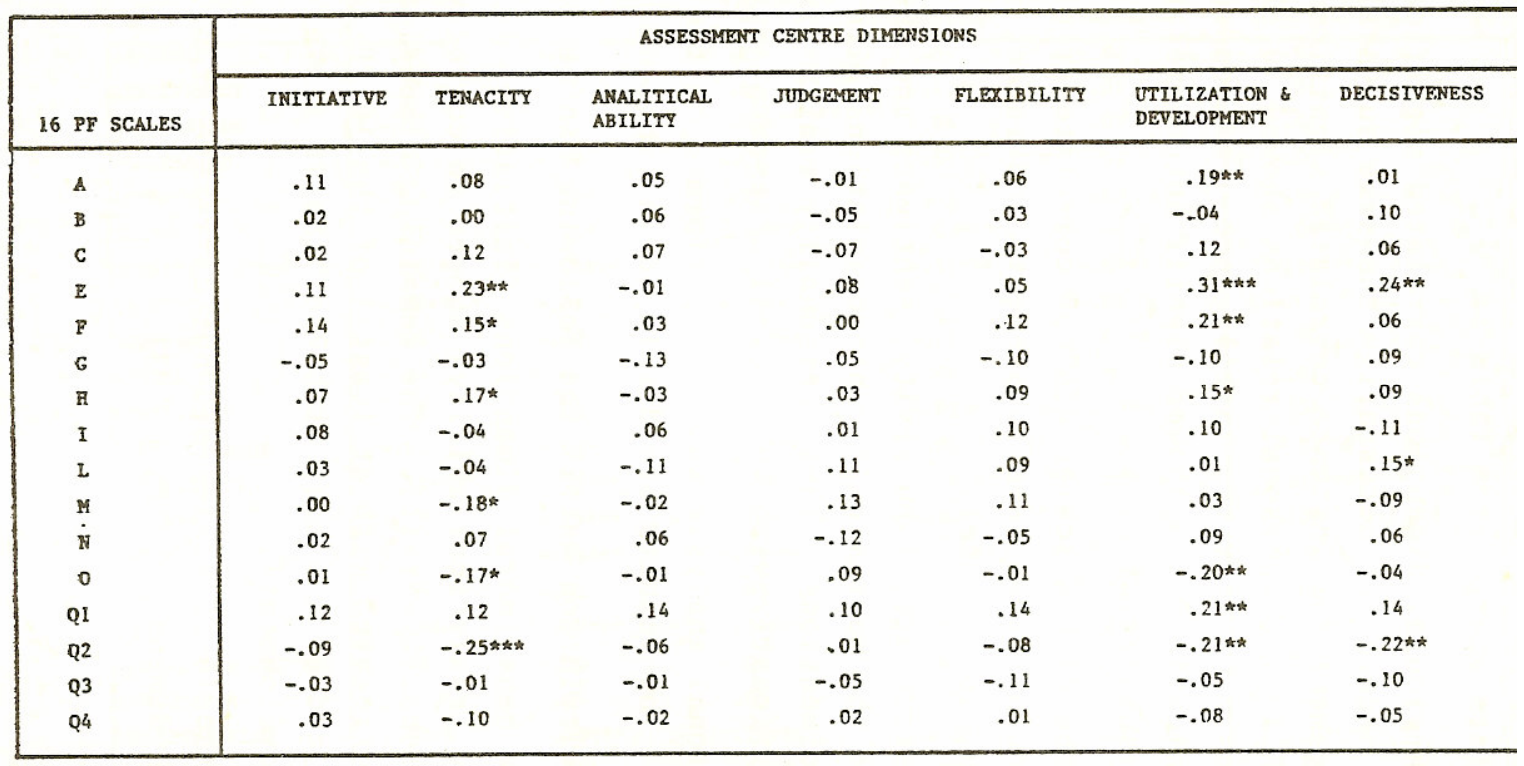

$* \mathrm{p}<.05)$

*⿻ $p<.01$ ) Two talled

$\leftrightarrow \mathrm{p}<.001$ )

TABLE 4 (CONTINUED)

\begin{tabular}{|c|c|c|c|c|c|c|}
\hline \multirow[b]{2}{*}{16 PF SCAT.ES } & \multicolumn{5}{|c|}{ ASSESSMENT CENTRE DIMENSIONS } & \multirow[b]{2}{*}{$\begin{array}{l}\text { OVERALL ASSESSMENT } \\
\text { RATING (OAR) }\end{array}$} \\
\hline & $\begin{array}{l}\text { TASR } \\
\text { STRUCTURING }\end{array}$ & EMPATHY & $\begin{array}{l}\text { RFASONING } \\
\text { ABILITY }\end{array}$ & $\begin{array}{l}\text { PRESENTATION } \\
\text { SRILLS }\end{array}$ & $\begin{array}{l}\text { PI.ANNING \& } \\
\text { ORGANIZING }\end{array}$ & \\
\hline A & .01 & .00 & .14 & $.19 k \star$ & .06 & .14 \\
\hline B & .04 & .06 & -.05 & .05 & .00 & .04 \\
\hline c & .13 & -.10 & -.10 & .10 & .10 & .09 \\
\hline E & $.19 *$ & .16 & .25 k\# & $.24 k \pi$ & .09 & $.26^{m \pi \hbar}$ \\
\hline $\mathbf{F}$ & $.17 *$ & .06 & .2 .2 ㅎ & .11 & .02 & $.17 *$ \\
\hline G & -.07 & $-.22 \pi *$ & -.05 & -.13 & .02 & .11 \\
\hline H & .13 & .04 & $.18 *$ & $.23 * \pi$ & .07 & $.16 *$ \\
\hline I & .06 & .11 & .02 & .07 & $.16 *$ & .10 \\
\hline L & -.06 & .00 & .05 & -.02 & .09 & -.03 \\
\hline$M$ & -.09 & -.01 & -.12 & -.01 & -.09 & -.09 \\
\hline N & .00 & -.03 & .19 k & .05 & .04 & .06 \\
\hline 0 & -.13 & .04 & .07 & $-.15 *$ & -.11 & -.12 \\
\hline$Q 1$ & .16 & .11 & $-.18^{t}$ & .12 & $.17 *$ & .21 k* \\
\hline Q2 & -.12 & .03 & $-.17 *$ & $-.18 *$ & -.06 & 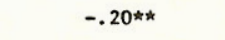 \\
\hline Q3 & .02 & -.09 & .03 & -.10 & .11 & .02 \\
\hline Q4 & -.10 & .00 & -.08 & -.05 & $-.17 *$ & -.08 \\
\hline
\end{tabular}

$\left.{ }^{*} p<.05 \quad\right)$

\# $\mathrm{p}<.01$ ) Two tailed

An $p<.001$ ) 
For both subject groups the analysis produced 2 discriminant functions, set out in Table 6 and Table 7 for the Canadian and South African groups respectively:

\begin{tabular}{|c|c|c|c|c|c|}
\hline \multicolumn{6}{|c|}{ TABLE 6} \\
\hline \multicolumn{2}{|c|}{ DISCRIMINANT } & ONS FOR & CANADIA & SUBJ & GROUP $(\mathrm{N}=1$ 199) \\
\hline FUNCTION & $\begin{array}{c}\stackrel{\circ}{\circ} \text { OF } \\
\text { VARIANCE }\end{array}$ & $\begin{array}{l}\text { WILKS' } \\
\text { LAMBDA }\end{array}$ & $\begin{array}{c}\text { CHI } \\
\text { SQUARE }\end{array}$ & $\mathrm{DF}$ & SIGNIFICANCE \\
\hline 1 & 83,9 & 0,940 & 73,2 & 22 &, 001 \\
\hline \multirow[t]{3}{*}{2} & 16,1 & 0,990 & 12,0 & 10 &, 28 \\
\hline & & TAI & 7 & & \\
\hline & \multicolumn{5}{|c|}{$\begin{array}{l}\text { DISCRIMINANT FUNCTIONS FOR THE SOUTH AFRICAN SUBJECT GROUP } \\
\qquad(\mathrm{N}=177)\end{array}$} \\
\hline FUNCTION & $\begin{array}{c}\circ \text { OF } \\
\text { VARIANCE }\end{array}$ & $\begin{array}{l}\text { WILKS ' } \\
\text { LAMBDA }\end{array}$ & $\begin{array}{c}\text { CHI } \\
\text { SQUARE }\end{array}$ & $\mathrm{DF}$ & SIGNIFICANCE \\
\hline 1 & 64,1 & 0,736 & 52,1 & 18 &, 001 \\
\hline 2 & 35,9 & 0,893 & 19,2 & 8 &, 025 \\
\hline
\end{tabular}

The standardized canonical discriminant function coefficients for the two subject groups are showed in Table 8 and Table 9: 
TABLE 8

STANDARDIZED CANONICAL DISCRIMINANT FUNCTION COEFFICIENTS

FOR THE CANADIAN SUBJECT GROUP $(\mathrm{N}=1$ 199)

\begin{tabular}{lcc}
\hline PRF SCALES & FUNCTION 1 & FUNCTION 2 \\
\hline Abasement &,- 25 &,- 02 \\
Agression &,- 13 &, 67 \\
Defendence &,- 18 &,- 34 \\
Dominance &,- 12 &,- 59 \\
Endurance &, 26 &, 29 \\
Harmavoidence &, 19 &, 50 \\
Impulsivity &, 66 &, 01 \\
Nurturance &,- 40 &, 12 \\
Play &, 09 &,- 44 \\
Sentience &, 59 &, 08 \\
Understanding &, 31 &, 21 \\
\hline
\end{tabular}

TABLE 9

STANDARDIZED CANONICAL DISCRIMINANT FUNCTION COEFFICIENTS FOR

THE SOUTH AFRICAN SUBJECT GROUP $(\mathrm{N}=177)$

\begin{tabular}{ccc}
\hline 16 PF SCALE & FUNCTION $i$ & FUNCT ION 2 \\
\hline C &, 25 &, 06 \\
E &, 40 &,- 71 \\
F &, 19 &, 57 \\
G &,- 30 &, 11 \\
I &, 48 &, 61 \\
L &, 03 &, 40 \\
M &,- 32 &,- 47 \\
Q1 &, 43 &,- 10 \\
Q2 &,- 03 &, 57 \\
\hline
\end{tabular}

The group centroids for the two subject groups are tabulated in Table 10 and Table 11. 
TABLE 10

GROUP CENTROIDS FOR THE CANADIAN GROUP $(\mathrm{N}=1199)$

\begin{tabular}{lccc}
\hline & FUNCTION & 1 & FUNCTION 2 \\
\hline "NO" &,- 283 &, 040 \\
'UNCERTAIN" &,- 004 &,- 257 \\
"YES" &, 214 &, 039 \\
\hline
\end{tabular}

TABLE 11

GROUP CENTROIDS FOR THE SOUTH AFRICAN GROUP $(\mathrm{N}=177)$

\begin{tabular}{lccc}
\hline & FUNCTION & 1 & FUNCTION \\
\hline 'NO" & 2 &, 581 \\
"UNCERTAIN" &,- 211 &,- 238 \\
'YES" &,- 248 &, 021 \\
\hline
\end{tabular}

The group centroids for both the Canadian and South African subject groups indicate that Function 1 differentiates the "Yes" candidates from the "No" and "Uncertain" candidates, while Function 2 differentiates the "Uncertain" candidates from the "Yes" and "No" candidates.

Based on the discriminant analysis, together with the correlational data already reported, the following deductions can be made:

- Canadian middle managers with managerial talent ("yes" candidates) can be characterized as being higher on impulsivity sentience and understanding and somewhat higher on endurance and harmavoidence. In contrast the managers without managerial talent ("No" candidates) tended to score higher on nurturance and somewhat higher on abasement, aggression, defendence and dominance.

- $\quad$ South African middle managers with managerial talent ("Yes" candidates) can be characterized as being higher on factors Q1 and E, somewhat higher on factors $\mathrm{C}$ and $\mathrm{F}$ and low on factors Q2 and G. In contrast the managers without managerial talent ("No" candidates) tended to score higher on Q2 and L and low on factors $\mathrm{E}$ and Q1. 
Strong similarities between the Canadian and South African subject groups emerged from both the correlational and discriminant function analysis. Very positive correlational similarities between the Canadian and South African subject groups were found. The results of the comparison are shown in Table 12.

TABLE 12

CORRELATIONAL SIMILARITIES BETWEEN THE CANADIAN SUBJECT GROUP $(\mathrm{N}=1199)$ AND THE SOUTH AFRICAN SUBJECT GROUP $(\mathrm{N}=177)^{\circ}$

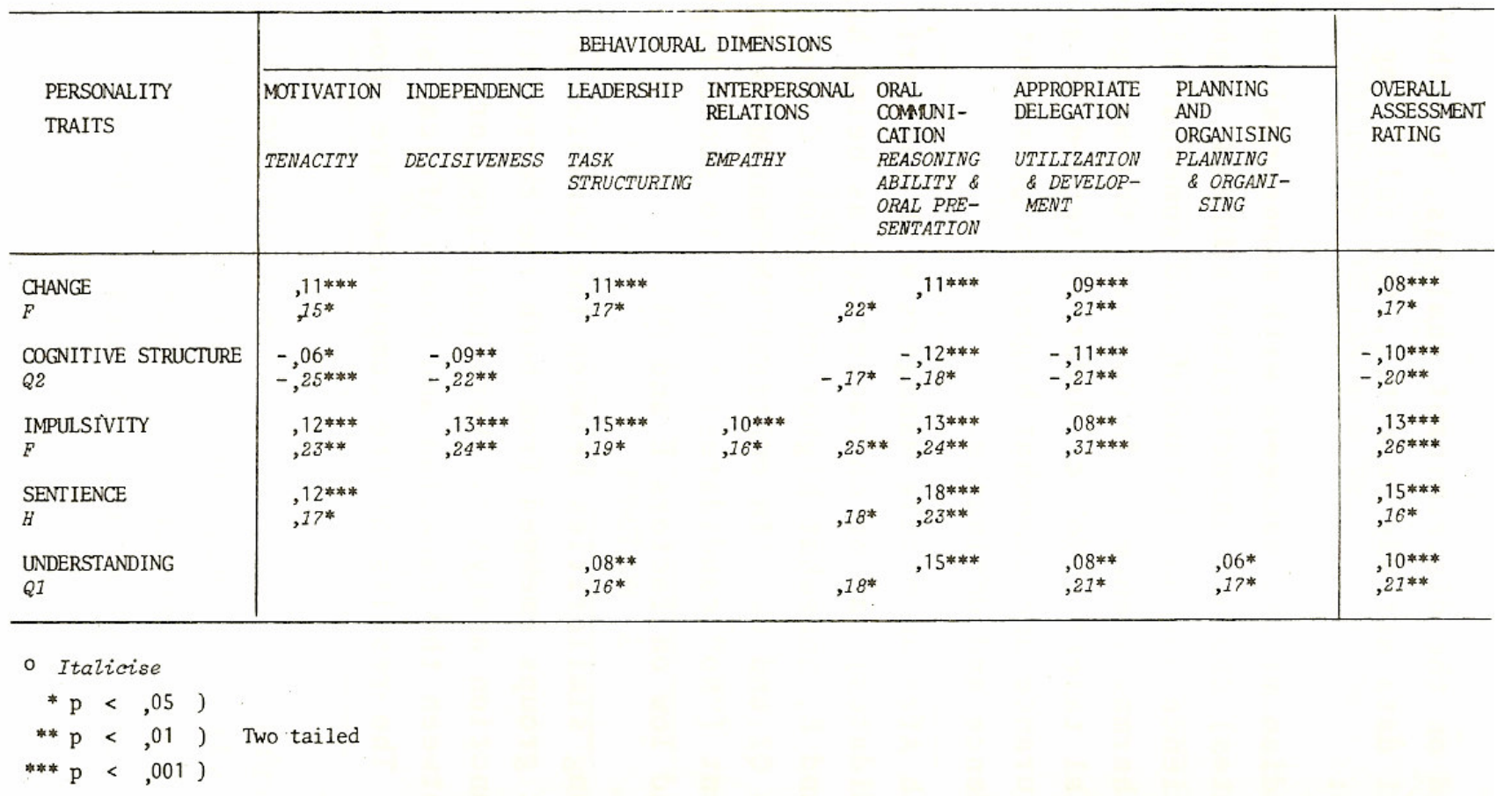

The various similarities in the results of the two correlational analyses, were found in the relationship between five personality traits and seven behavioural dimensions (see summary below):

\begin{tabular}{l|l}
\multicolumn{1}{c|}{\begin{tabular}{c}
\multicolumn{1}{c|}{ Personality } \\
Traits
\end{tabular}} & \multicolumn{1}{c}{\begin{tabular}{c}
\multicolumn{1}{c}{ Behavioural } \\
Dimensions
\end{tabular}} \\
\hline $\begin{array}{l}\text { Change (F) } \\
\text { Impulsivity (E) } \\
\text { Sentience (H) }\end{array}$ & $\begin{array}{l}\text { Motivation (tenacity) } \\
\text { Independence (decisiveness) }\end{array}$ \\
Understanding (Q1) & $\begin{array}{l}\text { Interpersonal relations (empathy) } \\
\text { Oral communication (reasoning ability } \\
\text { and oral presentation). Appropriate } \\
\text { delegation (utilization and de- } \\
\text { velopment) } \\
\text { Planning and organising (planning and } \\
\text { organising) }\end{array}$ \\
\hline
\end{tabular}


Oral communication was the only behavioural dimension that correlated significantly with all five personality traits. Interpersonal relations and planning and organising were the only dimensions which correlated with one personality trait only. The remaining dimensions correlated with at least two or more personality traits.

Among the personality traits, impulsivity (E) was the only trait which correlated with all but one of the behavioural dimensions. The remaining personality traits correlated with two or more behavioural dimensions.

All the correlational similarities between the personality traits and behavioural dimensions for the Canadian and South African subject groups were positive, except for those between cognitive structure (Q2) and the related behavioural dimensions, which were negative. On the surface the latter finding seems to be illogical, but when the high score descriptions of cognitive structure and Q2 are scrutinised, it becomes clear why talented managers tend to score low on these two personality traits (See Annexure 1 and Annexure 2).

Further outstanding correlational similarities were found in the relationship between the five personality traits and overall assessment rating (OAR). Again all the correlations were positive, except those between cognitive structure (Q2) and OAR.

A comparison of the two discriminant function analysis also indicated similarities between the Canadian and South African groups. Managers with potential ("yes" candidates) scored high on impulsivity (E) and understanding (Q1), while the managers without potential ("No" candidates) scored high on aggression (L), and defendence (L).

\section{CONCLUSION}

Based on these comparisons the personality profiles of the Canadian and South African managers appear to be similar. The overall conclusion reached is that the personality correlates of managerial talent seem to be culturally independent both for a total group of managers and for "high" and "low" talent managers. It is therefore possible to construct a capsule description of the personality profile and behavioural repertoire of a high talented manager. Such a description would run along the following lines:

The high talented manager: 
- $\quad$ likes new and different experiences

- $\quad$ is sensitive to many forms of experience

- dislikes routine

- $\quad$ adapts readily to changes

- $\quad$ is energetic, enthusiastic, resilient and resourceful

- $\quad$ freely expresses feelings and wishes

- $\quad$ is highly sociable

- $\quad$ speaks freely

- $\quad$ applies a "common sense" approach to problems and often makes decisions on guesstimates and probabilities

- $\quad$ is able to handle ambiguity and uncertainty in information

- $\quad$ tends to act on the "spur of the moment"

- $\quad$ tends to be self-centered, though not selfish

- $\quad$ is assertive, forceful and self-confident

- $\quad$ is able to absorb considerable amounts of wear and tear in emotionally charged interpersonal situations

- $\quad$ places a high premium on group support in taking action

- $\quad$ enjoys group activities and assumes leadership roles

- $\quad$ places a high value on synthesis of ideas, verifiable generalisations and logical thought

- $\quad$ has a desire to understand many areas of knowledge

- $\quad$ is an independent thinker

- $\quad$ is intellectually oriented with a strong inclination to question, analyse and often disparage traditional beliefs

- $\quad$ tends to be free-thinking and experimental in his approach to life

- $\quad$ finds it emotionally rewarding to put own ideas into action

- $\quad$ keeps himself well informed

- $\quad$ feels adequate at nearly any task

The findings of this study tempt one to make the assumption that universal personality correlates of managerial talent do exist. Further research to substantiate this assumption is necessary. 


\begin{abstract}
In spite of the worldwide use of the Managerial Assessment Centre, little, if any, cross-cultural research has been done on the method. Another neglected area of AC-research, is the study of personality. This study is aimed at making a contribution towards both these areas by investigating the relationship between the managerial dimensions and personality attributes for a group of Canadian $(N=1199)$ and a group of South African $(N=177)$ middle level managers. The first step was to compare the measuring instruments which were used to test the two groups, so as to ascertain any similarities and/or differences between the two instruments. The data which was generated by the application of the instruments was then subjected to a correlational and discriminant function analysis. The result of these analyses was used to (a) define the personality correlates of managerial talent and $(b)$ to identify broad tendencies with regard to the relative influence of culture on the relationship between personality and managerial talent.
\end{abstract}

\title{
REFERENCES
}

Bray, D.W. The assessment center and the study of lives. American Psychologist, 1982, 37, 180-189.

Bray, D.W. \& Grant, D.L. The assessment center in the measurement of potential for business management. Psychological Monographs, 1966, 80, 1-27.

Byham, W.C. What do we know about the assessment center? Proceedings of the 8th International Congress on the Assessment Center, Toronto, Ontario, Canada, June 1980.

Cattell, R.B., Eber, H.W. \& Tatsuoka, M.M. Handbook for the 16 PF. Illinois: Institute for Personality and Ability Testing, 1970.

Finkle, R.B. Managerial assessment centers. In Dunnette, M.D. (Ed.) Handbook of Industrial and Organizational Psychology. Chicago: Rand McNally, 1975.

Huck, J .R. Assessment centres: A review of the external and internal validities. Journal of Applied Psychology, 1973, 26, 191-212.

Jackson, D.N. Personality Research Form. Research Psychologists Press Inc., 1967.

Klimoski, R.J. \& Strickland, W.J. Assessment centers - valid of merely prescient? Personnel Psychology, 1977, 353-361. 


\section{ANNEXURE 1}

\section{HIGH SCORE DESCRIPTIONS OF THE PERSONALITY RESEARCH SCALES}

$S C A L E$

Abasement Shows a high degree of humility: accepts blame and criticism even

Achievement

Affiliation

Aggression

Autonomy

Change

Cognitive

Structure

Defendence

\section{HIGH SCORE DESCRIPTION}

when not deserved; exposed himself to situations where he is in an inferior position; tends to be self-effacing.

Aspires to accomplish difficult tasks; maintains high standards and is willing to work toward distant goals; responds positively to competition; willing to put forth effort to attain excellent.

Enjoys being with friends and people in general; accepts people readily; makes efforts to win friendships and maintain associations with people.

Enjoys combat and argument; easily annoyed; sometimes willing to hurt people to get his way; may seek to "get even" with people whom he perceives as having harmed him.

Tries to break away from restraints, confinement, or restrictions of any kind; enjoys being unattached, free, not tied to people, places, or obligations; may be rebellious when faced with restraints.

Likes new and different experiences; dislikes routine and avoids it; may readily change opinions or values in different circumstances; adapts readily to changes in environment.

Does not like ambiguity or uncertainty in information; wants all questions answered completely; desires to make decisions based upon definite knowledge, rather than upon guesses or probabilities.

Readily suspects that people mean him harm or are against him; ready to defend himself at all times; takes offence easily; does not accept criticism readily. 
Dominance Attempts to control his environment, and to influence or direct other people; expresses opinions forcefully; enjoys the role of leader and may assume it spontaneously.

Endurance Willing to work long hours; doesn't give up quickly on a problem; persevering, even in the face of great difficulty; patient and unrelenting in his work habits.

Exhibition Wants to be the center of attention; enjoys having an audience; engages in behaviour which wins the notice of others; may enjoy being dramatic or witty.

Harmavoidance Does not enjoy exciting activities, especially if danger is involved; avoids risk of bodily harm; seeks to maximize personal safety.

Impulsivity Tends to act on the "spur of the moment" and without deliberation; gives vent readily to feelings and wishes; speaks freely; may be volatile in emotional expression.

Nuturance Gives sympathy and comfort; assists others whenever possible, interested in caring for children, the disabled, or the infirm; offers a "helping hand" to those in need; readily performs favours for others.

Order Concerned with keeping personal effects and surroundings neat and organized; dislikes clutter, confusion, lack of organization; interested in developing methods for keeping materials methodically organized.

Play Does many things "just for fun"; spends a good deal of time participating in games, sports, social activities, and other amusements; enjoys jokes and funny stories; maintains a light-hearted, easy-going attitude toward life.

Sentience $\quad$ Notices smells, sounds, sights, tastes, and the way things feel; remembers these sensations and believes that they are an important part of life; is sensitive to many forms of experience; may maintain an essentially hedionistic or aesthetic view of life.

Social Desires to be held in high esteem by acquaintances; concerned about Recognition reputation and what other people think of him; works for the approval of recognition of others. 
Succorance Frequently seeks the sympathy, protection, love, advice, and reassurance of other people; may feel insecure or helpless without such support; confides difficulties readily to a receptive person.

Understanding Wants to understand many areas of knowledge; values synthesis of ideas, verifiable generalization, logical thought, particularly when directed at satisfying intellectual curiosity.

Desirability Describes self in terms judged as desirable; consciously or unconsciously, a-curately or inaccurately, presents favourable picture of self in responses to personality statements.

Infrequency Responds in implausible or pseudo-random manner, possibly due to carelessness, poor comprehension, passive non-compliance, confusion, or gross deviation. 


\section{ANNEXURE 2 \\ HIGH SCORE DESCRIPTIONS OF THE 16 PERSONALITY FACTOR QUESTIONNAIRE}

A High A scores are usually recorded by easy-going individuals who are generally warm-hearted, generous and adaptable in their interpersonal relationships. These persons tend to be sincere, cooperative and sympathetic with their associates. If married, they would probably be rated by their spouses as being soft-hearted and affectionate. High scores tend to be successful in careers requiring extensive interpersonal contacts.

B High B scores usually identify thoughtful, cultured individuals, with high intelligence.

These persons tend to be conscientious, persevering and self-assertive and are inclined to be alert and independent minded.

C High C scores usually identify emotionally stable individuals who act only after adequate deliberation and then proceed with patient perseverance. Such persons tend to be realistic, restrained, and constant in attitudes and interests and usually tend to be calm and even tempered.

E High E scores usually identify strongly individualistic persons who are selfassertive and confidently aggressive. Such individuals tend to be self-centered but not necessarily selfish. They tend to possess a healthy appetite for adventure and the capability for being dominant in many interpersonal relationships. Generally, they enjoy group activities and frequently assume leadership roles. These forceful and aggressive individuals must exercise considerable diplomacy and tact if they are to avoid provoking resentment in others.

F High F scores are usually recorded by sociable individuals who tend to be cheerful optimistic, and energetic. Such individuals tend to be resilient and resourceful and recover rapidly from anger. They usually possess an abundance of energy and a high level of enthusiasm. They tend to be quick in 
arriving at "common sense" solutions to problems. Generally, they enjoy travel and work that involves frequent change.

G High G scores usually identify persevering, conscientious individuals who readily accept and reliably discharge responsibility. These persons are generally self-exacting in character and often seem to be directed by an overpowering sense of duty. As a rule, they are hard workers who are serious, cultured and considerate of others. They may possess a somewhat puritanical regard for reputation.

$\mathrm{H} \quad$ High $\mathrm{H}$ scores usually identify socially self-confident individuals who tend to be bold, spontaneous, and uninhibited in their social interaction. These persons usually relate easily and comfortably "thick-skinned" and generally are capable of absorbing considerable amounts of wear and tear in emotionally charged interpersonal relations without undue exhaustion.

I High scores usually identify idealistic and gentle individuals who are inclined to be kindly, soft-hearted, and peace-giving. They may tend to be fastidious, artistic and given to daydreaming. When excited or threatened they tend to become fearful rather than angry. These persons generally gravitate toward work requiring skill and usually do not function at maximum effectiveness in physically demanding occupations.

L High L scores are usually recorded by moody individuals who tend to be cynical, fault-finding and markedly suspicious of the motives of others. These persons may find it difficult to fit into a group and generally make poor team workers, preferring self-sufficiency and independence to group action. Often they are jealous and possessive.

M High M scores usually identify distinctively individualistic persons who are self-motivated and imaginatively creative. Such individuals tend to be unconventional in many matters and their individuality may generate rejection by more practical and less creative associates. High scores are inclined to be wrapped up in their own inner thoughts to the external environment. Their apparent "absent-mindedness" is, in fact, introspective self-absorption and is simply an objectively observable feature of their creative thinking. 
$\mathrm{N} \quad$ High $\mathrm{N}$ scores are usually recorded by socially skilful individuals who are sophisticated and worldly wise. Such individuals tend to be free of sentimentality and wishful thinking and, as a rule, possess considerable insight into the motives of others.

O High O scores usually identify self-deprecating individuals who tend to brood and worry excessively. These persons tend to be emotionally very sensitive, tend to become easily discouraged, and are inclined to harbour troublesome feelings of inferiority and inadequacy in meeting even the routine demands of daily life. Anyone therefore may merit clinical evaluation.

Q1 High Q1 scores are usually obtained by independent thinking, intellectually oriented individuals who are strongly inclined to question, analyse, and often disparage traditional beliefs. Such individuals tend to be free-thinking and experimental in their approach to life.

They enjoy work involving critical analysis, feel comfortable in working alone on projects of interest to them, and find it emotionally rewarding to put their own ideas into action. High scores on this index generally keep themselves well informed, tend to feel adequate to nearly any task, and usually welcome positions of leadership.

Q2 High Q2 scores usually identify decisive and resourceful individuals. They do not seek the agreement of associates and do not require group support in taking action. Such independent-minded individuals are not suggestible and are not influenced greatly by public opinion.

High scorers are in the habit of going their own way and may tend to be seclusive, considering most social activities to be wasteful of time.

Q3 High Q3 scores are usually recorded by self-assured individuals who consistently maintain a disciplined control over their behaviour.

Such socially correct individuals take care to comport themselves as gentlemen and ladies in interpersonal relationships. They carefully attend to manners, morals and the maintenance of a good reputation. They are inclined to be effective in guarding against impulsive actions and in resisting temptations of the moment. They avoid insult and injury to their self-respect by consistently behaving in a manner which they themselves find socially 
acceptable. Their thinking tends to be carefully organised and they tend to express their emotions in a controlled and precise manner.

Q4 High Q4 scores are usually recorded by tense and irritable individuals who are easily annoyed by trivial matters. Such individuals tend to be overwrought and restless. They also tend to be impatient and excitable and can lose their temper easily. Even when tired, these individuals often remain restless and pressured to activity. They are likely to feel frustrated and unsatisfied and they tend to be easily moved to alarm or to anger. High Q4 scores are often associated with transient situational disturbances. 